Juliusz B a rd a ch

\title{
Statuty litewskie w Koronie Królestwa Polskiego
}

\section{Litauische Statuten in der Krone des Polnischen Königsreiches}

1. Statuty litewskie w historiografii prawniczej. 2. Wpływ Statutów na praktykę sądownictwa krajów ościennych. 3. III Statut litewski w Koronie. 4. III Statut w kompendiach prawników polskich. 5. Bezpośrednia recepcja przepisów III Statutu. 6. Znaczenie III Statutu w rozwoju polskiego prawa. 7. Wpływ Statutów litewskich na prawodawstwo polskie w XVIII w. 8. III Statut po upadku Rzeczypospolitej.

1. Litauische Statuten in der juristischen Historiografie. 2. Der Einfluß der Statuten auf die Gerichtspraxis der Nachbarländer. 3. Das III litauische Statut in der Krone. 4. Das III Statut in den Kompendien der polnischen Juristen. 5. Direkte Rezeption der Gesetze des III Statutes. 6. Bedeutung des III Statutes für die Entwicklung polnisches Rechtes. 7. Der Einfluß der litauischen Statuten auf polnische Gesetzgebung im XVIII Jahrhundert. 8. Das III Statut nach dem Verfall der polnisch-litauischen Commonwaeith.

1. Znaczenie Statutów litewskich dla prawa koronnego i jego praktyki doceniała od początku polska historiografia prawnicza ${ }^{1}$. Uznawany za pierwszego historyka prawa Tadeusz Czacki zatytułował swoje podstawowe dzieło $O$ litewskich $i$ polskich prawach, o ich duchu, źródlach, zwiazku $i$ o rzeczach zawartych $w$ pierwszym Statucie dla Litwy w 1529 roku wydanym (t. 2: 1800-1801)2. Eksponował on, szerzej niż określał to tytul, w przedstawieniu pracy Rzeczypospolitej Obojga Narodów prawo litewskie, któremu przyznawal priorytet w stosunku do prawa koronnego. T. Czacki nie ograniczył się do I Statutu, ale sięgnął też porównawczo, do dwóch następnych. Odróżniał on trzy odrębne Statuty, kwestionując ujmowanie ich jako kolejne redakcje jednego pomnika prawa. Stanowisko to podzieliła, choć nie bez wyjątków, późniejsza nauka histo-

\footnotetext{
${ }^{1}$ Pierwszy zarys tematu był przedmiotem referatu autora tego tekstu na konferencji w Wilnie w 1988 r. z okazji 400-lecia III Statutu litewskiego. Został on opublikowany w języku litewskim pt. Lietuvos Statutas Lenkijoje, [w:] 1588 metu trečiasis Lietuvos Statutas, Vilnius 1989 , s. $17-27$.

${ }^{2}$ Wydanie 2, Kraków 1861; wydanie fotoffsetowe (z wydania 1), Warszawa 1987.
} 
rycznoprawna ${ }^{3}$. Podsumowując jej dorobek, Stefan Ehrenkreutz na VI Powszechnym Zjeździe Historyków Polskich w Wilnie we wrześniu 1935 r. ponownie stwierdzał, że każdy z tych Statutów stanowi dla siebie zamknieta calosíc $c^{4}$.

W tym miejscu zajmiemy się przede wszystkim III Statutem litewskim wprowadzonym w życie w roku 1588 i opublikowanym $w$ tymże roku drukiem $w$ ruskim (starobiałoruskim) oryginale, a następnie w 1614 r. w polskim przekładzie. Byl III Statut najdoskonalszą kodyfikacją, na jaka zdobyto się na ziemiach Rzeczypospolitej Obojga Narodów. Toteż pozostawał on jako prawo obowiązujące na ziemiach byłego Wielkiego Księstwa aż po rok 1840, kiedy cesarz Mikołaj I uchylił jego moc obowiązującą, wprowadzając $\mathrm{w}$ to miejsce prawo rosyjskie ${ }^{5}$.

Tekst III Statutu w polskim przekładzie, kilkakrotnie przedrukowywanym i uzupełnianym o postanowienia późniejszych konstytucji sejmów walnych Rzeczypospolitej Obojga Narodów, regulowal nie tylko życie prawne ziem Litwy i Białorusi, ale znalazł też zastosowanie w praktyce prawnej ziem ruskich i polskich Korony Królestwa Polskiego. To właśnie będzie przedmiotem naszego zainteresowania.

Już w połowie XIX w. Wacław Aleksander Maciejowski w syntetycznym skrócie ocenił miejsce III Statutu w prawodawstwie europejskim i metaforycznie określił jego wzajemny do sąsiednich systemów prawnych stosunek. Pisał on: Wielkim jak na swój wiek pomnikiem prawodawstwa jest litewski Statut $i$ taki, jakiego ówczesna Europa nie posiadala. Jest jakby roślina, która krzewiacych sie obok drzewek przyciagnqwszy do siebie soki, nimi sie zapomogla, a przerobiwszy je $w$ sobie, oddala je znowu jako lepsze pożywniejsze $e^{6}$.

Zwróćmy tu uwagę na dwa akcenty. Pierwszy - to podkreślenie wzajemnego oddziaływania, określanego dziś jako inkulturacja w przeciwieństwie do akulturacji, która jest formą wpływów jednostronnych. Drugi - to wysoka ocena Statutu litewskiego (domyślnie III), którego oddziaływania na kraje sąsiednie był Maciejowski w pełni świadom.

Na przełomie XIX i XX stulecia w nauce polskiej zaznaczyl się prąd, który nie negując walorów Statutów litewskich, jako wybitnych osiągnięć kultury prawniczej, zaliczał je do prawa polskiego. Tak postąpił w szczególności Franciszek Piekosiński, choć wyróżniał w nim prawo koronne i prawo

\footnotetext{
${ }^{3}$ Jej poglądy w XIX i pierwszym dwudziestoleciu XX w. obszernie przedstawił S. Ehren k reutz, Stan badań nad Statutami litewskimi, Ateneum Wileńskie, t. II, 1924, s. 289-349.

${ }^{4}$ S. Eh re nk r u tz, Zagadnienie wplywu prawa rzymskiego na Statuty litewskie, [w:] Pamiętnik VI Powszechnego Zjazdu Historyków Polskich w Wilnie 17-20 września 1935 roku, t. I, Referaty, Lwów 1935, s. 193-194.

${ }^{5} \mathrm{~J}$. Bardach, Statuty litewskie $w$ ich kregu prawno-kulturowym, [w:] $O$ dawnej i niedawnej Litwie, Poznań 1988, s. 39-71.

${ }^{6}$ M. M a ciejowsk i, Historia prawodawstw slowiańskich, t. I, wyd. 2, Warszawa 1856, s. 207.
} 
litewskie ${ }^{7}$. Ten wydawca tekstu łacińskiego i przekładu polskiego II Statutu z $1566 \mathrm{r}$. oryginał ruski tej kodyfikacji w ogóle pominą1 ${ }^{8}$. W obronie jego przed krytyką ukraińskiego historyka, wystappił Oswald Balzer w polemicznym artykule zatytułowanym: Profesor Piekosinski i Statuty litewskie... (1907). O. Balzer podzielił ogół norm zawartych w Statutach na polskie i niepolskie. Taki podział miał pozwolić, jego zdaniem, na ukazanie, że są cale dzialy prawa, przeważnie wedlug modly polskiej urzqdzone. Należały tu przepisy dotyczące organizacji naczelnych i lokalnych władz państwowych, organizacji sądów, także prawo cywilne i procesowe. W ten sposób - pisał Balzer - wiele dziedzin prawa obowiazujacego na Litwie zostalo jak gdyby zdobytych przez prawo polskie. Uznając, że na Statuty litewskie złożyły się elementy różnorodne, bo polskie, litewskie, ruskie i niemieckie, O. Balzer podkreślal, że rolę decydującą odgrywal element polski, bowiem to on je sprzega wszystkie w jednolitq organicznq calość. [...] Możemy $w$ tym sensie nazwać Statuty litewskie pomnikami prawa polskiego ${ }^{9}$. Intencją O. Balzera było podkreślenie wyższości prawa polskiego. Niewątpliwy wpływ tego ostatniego na organizację systemu administracyjnego i urzędów, po części i sądownictwa, rozciągał $\mathrm{O}$. Balzer i na prawo sądowe. Jednak tu - gdy chodzi o wpływy - należało mówić raczej o oddziaływaniu uczonego prawa, gdyż w całości przedstawiają się Statuty litewskie jako rezultat złożonej twórczości kodyfikacyjnej dokonywanej w wieloetnicznym środowisku prawniczym Wielkiego Księstwa doby Odrodzenia. Ich podstawowym założeniem było doskonalenie systemu prawa Litwy historycznej. Dlatego też należy uznać je za oryginalny, własny wkład kodyfikacyjnej myśli Wielkiego Księstwa Litewskiego, więcej - za historyczne osiągnięcie.

2. Wysoki poziom litewskich kodyfikacji docenili rychło wszyscy sąsiedzi Wielkiego Księstwa. Najwcześniej, bo już w stosunku do II Statutu, dały temu wyraz społeczności szlacheckie Wołynia, Kijowszczyzny i Podola (województwa bracławskiego), które po inkorporacji do Korony Królestwa na sejmie lubelskim 1569 r. zastrzegły, że prawem obowiązującym pozostanie nadal II Statut litewski, zwany odtąd potocznie Statutem wołyńskim,

'F. Piekosiński, Statut litewski, cz. I, RAU. WH-F [Kraków] 1899, t. XXXIX, s. 166.

${ }^{8}$ AKP AU [Kraków] 1900, t VII. Ruski tekst II Statutu opublikowany we Wriemienniku Moskowskogo Obszczestwa Ljubitieiej Driewnostiej Rossijskich, t. XXIII, w 1855 r., o czym Ulanowski nie wiedział, był $\mathrm{w}$ istocie Statutem wołyńskim. Wskazuje na to $\mathrm{m}$. in. nota przy rozdziale III $O$ obronie ziemskiej, że nie jest obowiązujący. Znana jest też osoba kopisty. Był nim Wasyl Usowicz pisarz grodzki i syndyk kijowski w pierwszej połowie XVII w. Egzemplarz należał do Biblioteki Załuskich (Catalogus cod. mns. 1752, p. 68 N 213). Tekst został wydany z licznymi błędami, które nie wiemy komu przypisać - kopiście czy wydawcy.

${ }^{9}$ Przedruk [w:] O. Balzer, Przygodne slowa 1886-1911, Lwów 1912, s. 183-197, zwłaszcza s. 190-196. 
w odróżnieniu od III Statutu litewskiego z $1588 \mathrm{r}^{10}{ }^{10}$ Pozostaje do zbadania, kiedy zaczęto $\mathrm{z}$ niego korzystać jako prawa posilkowego w sądach koronnych, a także, jaką rolę odegrał tu Trybunal Koronny, który (po likwidacji istniejącego krótko Trybunału Luckiego) na sesjach w Lublinie rozpatrywał sprawy województw ukrainnych, rządzących się II Statutem. Należy sądzić, że mnożące się polskie rękopiśmienne przekłady II Statutu (na znanych nauce 58 egzemplarzy, aż 40 jest $w$ wersji polskiej) ${ }^{11}$ były również rezultatem zainteresowania tyleż deputatów Trybunału, co i skupionej wokół niego palestry.

Jeśli uprawniona jest hipoteza, że początki wpływu prawa litewskiego na praktykę sądów koronnych łączą się ze znajomością II Statutu, to nie ulega wątpliwości, że upowszechnienie znajomości prawa litewskiego lączy się z publikacją $w$ precyzyjnym polskim przekładzie z 1614 r. III Statutu. To i następne polskie wydania zbliżyły prawo litewskie do praktyki i spowodowały, że w XVII $w$. stało się ono prawem posiłkowym $w$ sądach koronnych. Przemyslaw Dąbkowski, nota bene uczeń O. Balzera, podkreślał, że prawo litewskie było prawem posiłkowym w sądach koronnych w XVII i XVIII w., a to dzięki temu, że III Statut stanowil zbiór praw wyczerpujacy $i$ jak na swoje czasy doskonaly ${ }^{12}$. Jeszcze dalej poszedł $\mathrm{w}$ tym kierunku profesor prawa karnego również Uniwersytetu Lwowskiego Juliusz Makarewicz. Wykorzystując teksty dawnych polskich pisarzy prawniczych, stwierdzał, że III Statut był stosowany w. Polsce nie tylko jako prawo posiłkowe, ale że w XVIII w. wytworzyło się przekonanie, i stanowi on drugi, równorzędny $\mathrm{z}$ koronnym, obowiązujący system prawa ${ }^{13}$. Czy tak daleko posunięta promocja prawa litewskiego w Polsce była uzasadniona? Należy uznać za dowiedzione stosowanie prawa litewskiego jako posiłkowego. Przyczyny tego zjawiska zostały wyjaśnione przez naukę. Mianowicie, wobec nieskodyfikowania polskiego prawa ziemskiego - które poza procedurą sądową (Formula Processus - 1523) pozostało w znacznej mierze prawem zwyczajowym, unormowanym tylko w części przez królewskie Statuty i konstytucje sejmowe - w prawie sądowym Korony występowały liczne luki, sprzeczności lub niejasności. W tej sytuacji istnienie nowoczesnej, wysoko cenionej kodyfikacji w sfederowanym Wielkim Księstwie Litewskim, do tego znanej $\mathrm{w}$ polskim przekladzie, wielokrotnie wydawanym drukiem, więc latwo dostępnym, zachęcało do korzystania z III Statutu, gdy brak

${ }^{10}$ O Statucie wołyńskim wiemy dotąd niewiele. Krótko o nim B. Ulanowski we wstępie do Wydania II Statutu, AKP, t. VII, s. V-VI, i S. Kutrzeba, Historia źródel, t. II, Kraków 1926, s. 79 n.

"V. R audeliūnas, Antrojo /1566/ Lietuvos Statuto nuorašai, [w:] Teisisiniu institutu Raida Lietuvoje XIV-XIX a. Teisés istorijos studijos II, Vilnius 1981, s. 6-30.

12 P. Dąbkowski, Prawo prywatne polskie, t. I, Lwów 1910, s. 6.

13 J. Makarewicz, Polskie prawo karne. Czesśc ogólna, Lwów 1919, s. 18-19. 
było odpowiedniej normy w prawie polskim, lub gdy byla ona niejasna czy przestarzała.

Próbę syntetycznego ujęcia stanu badań podjąl na VI Powszechnym Zjeździe Historyków Polskich we wrześniu 1935 r. Wojciech Hejnosz w referacie, którego tytul brzmial: Statuty litewskie a prawo polskie. Najpierw z ukłonem przed pamięcią swego mistrza Oswalda Balzera stwierdzil, że według communis opinio polskich badaczy Statut litewski to polski pomnik prawodawczy, ale zaraz potem zastrzegl się, że przez prawo polskie rozumie on prawo na terenie całej Rzeczypospolitej. Gdy natomiast weźmie sie pod uwage - wywodzil dalej - prawo polskie sensu strictiori, tzn. jako prawo ziemskie koronne, to już trudno byloby uważać Statut za pomnik tego prawa. $W$ takim razie można by mówić już tylko o wzajemnym stosunku [...] ściśle mówiqc, o wplywie, jaki najpierw to prawo na Statut, wzglednie na poszczególne jego redakcje wywarlo, a nastepnie także o późniejszym oddzialywaniu Statutu na rozwój prawa polskiego ${ }^{14}$. To wyważone stanowisko daleko odbiegało od wstępnej deklaracji.

3. Badania nad zakresem stosowania III Statutu w Koronie zostały zaledwie zapoczątkowane. Przede wszystkim należy rozróżnić, kiedy w praktyce Trybunału Koronnego stosowano prawo litewskie jako jedynie obowiązujące, a kiedy jako posilkowe. W tej pierwszej kategorii spraw odnoszących się do województw ukrainnych wymaga zbadania zagadnienie, jak przebiegało w praktyce zastąpienie nie uchylonego nigdy, więc formalnie obowiązującego, Statutu II (wołyńskiego) Statutem litewskim. Że dobą krytyczną były lata trzydzieste i czterdzieste wskazywać się zdaje konstytucja $1647 \mathrm{r}$. uchwalona przez sejm walny na prośbę szlachty wołyńskiej. Przewidywala ona wydanie drukiem na jej koszt oryginalnego tekstu Statutu wołyńskiego ${ }^{15}$, do czego jednak nie doszło. Można sądzić, że uchwała ta stanowiła próbę utrzymania obowiązującego Statutu wołyńskiego w obliczu ekspansji III Statutu w praktyce. Zakończyła się ona niepowodzeniem i w drugiej połowie XVII w. III Statut na Ukrainie wyparł Statut wołyński. Można o tym sądzić na razie na podstawie ulamkowych badań praktyki, jak akty księgi sądu miejskiego (ratuszowego) miasta Lochwicy $\mathrm{z}$ lat $1653-1683^{16}$. W tej dobie Łochwica wchodziła w skład tzw. Ukrainy hetmańskiej. Jej organizacja terytorialna była oparta na okręgach pułkowych i na niższym szczeblu secinnym. Lochwica była miastem secinnym. Na ogólną liczbę 214 wpisów

\footnotetext{
${ }^{14}$ W. Hejnosz, Statuty litewskie a prawo polskie, [w:] Pamiętnik VI Powszechnego Zjazdu..., t. I, s. 199-200.

is VL, t. IV, s. 117 (wydanie J. Ohryzki, Petersburg 1859, t. IV, s. 59), punkt 52.

${ }^{16}$ A. Zakrzewski, recenzja z: Lochwicka ratuszna kniha druhoj polowiny XVII st., (Kijów 1986, ss. 222), CPH 1989, t. XLI, z. 1, s. 177-178.
} 
61 razy powołano różne artykuły III Statutu, jeden raz prawo niemieckie (Sakson), ani razu natomiast nie ma powołania na Statut wołyński. Są dwa powołania na Statut koronny, ale $\mathrm{z}$ analizy tekstu wynika, że sądowi chodziło w istocie o Statut litewski. Można sądzić, że określenie „Statut koronny" przez sąd na formalnie podległej carowi moskiewskiemu hetmańskiej Ukrainie mogło oznaczać stosowanie Statutu wołyńskiego, znanego głównie - jak wiemy - z przekładów polskich, obowiązującego na ziemiach prawobrzeżnej Ukrainy wchodzącej w skład Korony Królestwa Polskiego. Podsumowując można powiedzieć, że w drugiej połowie XVII w. III Statut litewski stanowił de facto prawo obowiązujące na ziemiach zarówno lewobrzeżnej, jak i prawobrzeżnej Ukrainy, oraz prawo posilkowe na pozostałych ziemiach Królestwa Polskiego.

4. Wiedzę o roli prawa litewskiego w Koronie należy uzupełnić o niezauważoną dotąd przez historyków prawa twórczość Augustyna Kołudzkiego (zm. 1720) - sędziego ziemskiego inowrocławskiego. Był on autorem dwutomowego dzieła o lacińskim tytule: Promptuarium legum et constitutionum Regni Poloniae et Magni Ducatus Lithuaniae ${ }^{17}$ wydanego dwukrotnie w latach 1695 i 1697 w Poznaniu. Tom pierwszy obejmował prawo koronne, drugi - litewskie. W rok później Kołudzki wydał już tylko tom drugi jako osobny druk pod polskim tytułem: Statut Wielkiego Ksiestwa Litewskiego. Jego materie obejmujące również konstytucje uchwalone po 1588 r., a dotyczące przedmiotów regulowanych przez Statut, były ułożone według treści w siedmiu rozdziałach $^{18}$. Zapotrzebowanie na ten tekst było widocznie większe niż na dwutomowe dzielo obejmujące łącznie prawo koronne i litewskie, skoro dodatkowo wydano go osobno. Można sądzić, że w Koronie istniało zapotrzebowanie na Promptuarium Legum Rzeczypospolitej Obojga Narodów, gdy na Litwie wystarczała znajomość tylko systemu prawa litewskiego, bo znajomość prawa koronnego była dla praktyków Wielkiego Księstwa bezużyteczną. Można by to również tłumaczyć tym, że w miarę upowszechnienia prawa litewskiego jako posiłkowego prawnicy polscy odczuwali potrzebe uzupełnienia swoich księgozbiorów o podręczną księge o III Statucie. Zainteresowanie dziełami A. Kołudzkiego świadczy dowodnie, że u schyłku XVII w. prawo litewskie weszło na trwale do prawniczej praktyki polskiej.

Dowodem na to jest wydane tuż potem dobrze znane literaturze dzieło Mikołaja Zalaszowskiego Ius Regni Poloniae (t. I - 1699, t. II - 1703). W podtytule autor wskazał, że system prawny Królestwa Polskiego był

\footnotetext{
${ }_{17}^{17}$ K. Estreicher, Bibliografia polska XV-XVIII w., t. XIX, Kraków 1903, s. 430-431.

${ }^{18}$ Egzemplarz tego dzieła A. Kołudzkiego znajduje się w bibliotece filii Muzeum Narodowego w Nieborowie, sygn. 363 .
} 
ex statutis, constitutionibus eiusdem Regni et $M$ (agni) D(ucatu) L(ithuaniae) collectum et addicioibus ex iure civili romano, canonico, saxonico etc. illustratum. Jak stąd wynika - i co potwierdza również analiza treści dzieła - Zalaszowski uważal prawo litewskie za prawo stosowane w Królestwie Polskim, podczas gdy inne prawa były powoływane dodatkowo dla uzupelnienia wiedzy o przedstawianych instytucjach prawnych. Dlatego też Zalaszowski prezentował normy Statutu szczególowo, najczęściej in extenso, gdy postanowienia Korektury pruskiej streszczał własnymi słowy, wskazując na ich związek $\mathrm{z}$ prawem chelmińskim ${ }^{19}$. Już przed póltora wiekiem R. Hube w swojej młodzieńczej pracy (z 1830 r.) zwrócił uwage, że Zalaszowski przedstawił z jednej strony prawa krajowe, czyli koronne i litewskie, z drugiej wszystkie inne. Te ostatnie omawial szerzej tam, gdzie prawa krajowe niedostatecznie podawaly pojecia prawne, jak się wyrażał, pro meliori resolutione huius tituli $i^{20}$.

Miejsce i rola III Statutu w życiu prawnym Królestwa Polskiego zostały zarysowane precyzyjnie w dziele Teodora Ostrowskiego Prawo cywilne albo szczególne Narodu Polskiego z statutów i konstytucji koronnych i litewskich zebrane (t. I-II, Warszawa, wyd. 1 - 1784, wyd. 2 - 1787). Ostrowski odróżniał prawo koronne i litewskie, które nazywał prawami krajowymi lub prawami obojga narodów. Prawo litewskie w Koronie miało - według niego - moc prawa posiłkowego, ponieważ bedqc prawem municypalnym prowincji jednego narodu, w niedostatku koronnego zawsze $w$ sadach naszych miewa swoja powage. To sformułowanie na wstępie dzieła uzupelniał Ostrowski stwierdzeniem, że dzieje się tak dlatego, że $w$ wielu artykułach prawodawstwo koronne nie dorównywa doskonalości litewskiego ${ }^{21}$. Toteż - jak ustalał badacz twórczości Ostrowskiego - ustęy poświęcone prawu litewskiemu zajmuja pokaźnq część Prawa cywilnego [...] Narodu Polskiego ${ }^{22}$.

5. Zwróćmy z kolei uwage na wypadki recepcji bezpośredniej. Mianowicie, gdy w 1768 r. w Koronie wprowadzono karę śmierci za umyślne zabójstwo chłopa - o którą dopominal się jeszcze Andrzej Frycz Modrzewski - oparto się na odpowiednim przepisie III Statutu, wyraźnie się na niego powołując. Gdy nie tylko prawa boskie, ale też ustawy ojczyste narodowe, mianowicie Statut $W$.X. Lit. $w$ artykule pierwszym $w$ rozdziale dwunastym $i$ konstytucja 1726 r. sub titulo: Méżobójstwo mieć chcq i nakazujq ${ }^{23}$ - czytamy we wstępie do nowej ustawy.

19 I. Malinowska-Kwiatkowska, Mikolaj Zalaszowski, polski prawnik XVII stulecia na tle ówczesnej nauki prawa, Kraków 1960, s. 63 n., 107.

${ }^{20} \mathrm{R}$. H u be, O dawnych pisarzach prawa karnego w Polsce, [w:] Pisma, t. I, Warszawa 1905, s. $128-130$.

${ }^{21}$ Z. Zdrójkowski, Teodor Ostrowski (1750-1802), pisarz dawnego polskiego prawa sqdowego, Warszawa 1956, s. 200, 203-204.

22 Ibidem, s. 204.

23 VL, t. VII, s. 600 , (wyd. 1860, s. 280). 
W procesie o porwanie króla Stanisława Augusta, w listopadzie $1771 \mathrm{r}$. oskarżyciel Jan Nepomucen Słomiński powoływał się na prawa narodowe, konstytucje z r. 1588, a wyraźniej (na) Statut litewski $w$ rozdziale I artykul 3, oskarżając podsądnych o zbrodnię obrazy majestatu (crimen laesae maiestatis). Podobnie drugi oskarżyciel Antoni Rogalski, powolując konstytucje koronne, stwierdzil, że Statut narodu litewskiego $w$ tych samych okolicznościach zgadza się we wszystkim $z$ prawem koronnym ${ }^{24}$. Sąd sejmowy jednak w wyroku powolał się tylko na konstytucję koronną z 1588 r., co przemawiałoby za uznawaniem przez ten sąd prawa litewskiego jako posilkowego, na które się nie powoływano, gdy istniała norma $w$ prawie koronnym.

W kilkanaście lat potem $\mathrm{T}$. Ostrowski w wypadku crimen laesae maiestatis wobec niesprecyzowania kary $w$ prawie koronnym zalecal stosowanie kary przewidzianej przez III Statut litewski ${ }^{25}$. Zwracając uwage na sprzeczności przepisów III Statutu z normami Statutów Kazimierza Wielkiego, Ostrowski zauważał: Różność praw tych $w$ rzeczy tak istotnej arcyszkodliwa $i$ niebezpieczna zastanowic powinna wladze prawodawcz ${ }^{26}$. Uwagi tej pisarz nie formulowalby, gdyby nie zachodziło niebezpieczeństwo sprzeczności w judykaturze, na skutek możliwości stosowania przez sądy alternatywnie przestarzałych przepisów prawa koronnego (w tym wypadku Statutów Kazimierza Wielkiego z polowy XIV w.) i późniejszych o przeszło dwa wieki norm Statutu litewskiego z $1588 \mathrm{r}$.

6. Na pozycję III Statutu w systemie prawa polskiego wskazuje fakt, że po I rozbiorze w Galicji, cesarzowa Maria Teresa patentem z 2 grudnia 1775 r. uznała III Statut jako prawo posiłkowe dla zwyczajowego głównie polskiego prawa spadkowego ${ }^{27}$.

Rola III Statutu jako równorzędnej ze Statutem Łaskiego (1506 r.) podstawy $w$ stosunkach między panem a poddanym $w$ Polsce znalazła wyraz w literaturze, kiedy Franciszek Zabłocki w wystawionej w 1785 r. komedii Sarmatyzm, kazał mówić Regentowi:

Koronny i litewski Statut nam to powi, Co chlopu szlachcic, chlop co winien szlachcicowi.

\footnotetext{
${ }^{24}$ W. Ostróży ński, Sprawa zamachu na Stanislawa Augusta 23 listopada 1771 roku przed sqdem sejmowym, Lwów 1891, s. 91, 133-138.

${ }^{25}$ T. Ostrowski, Prawo cywilne, t. I, s. 299.

${ }^{26}$ O tym J. M akarewicz, Polskie prawo karne, s. 16, przyp. 3.

${ }^{27}$ J. T. Wawel-Louis, Poczqtkowe sqdownictwo austriackie w Galicji 1772-1784, Lwów 1897 , s. 15.
} 
Analizując praktykę sądów polskich w sprawach karnych w XVIIXVIII w., w kontekście roli w nich III Statutu, Józef Rafacz zwracal uwage, że wplyw prawa karnego litewskiego przejawial sie w procesie karnym polskim ziemskim $w$ dwojaki sposób. Pierwszy polegal na stosowaniu przez sędziego [...] przepisu wziętego z prawa litewskiego. Należały tu: stosowanie kwalifikowanych kar śmierci za morderstwo dokonane na szlachcicu czy odroczenie wykonania wyroku śmierci na ciężarnej kobiecie. Drugi - to przyjęcie przez polską judykaturę instytucji prawa karnego litewskiego, wyrażających nowoczesne rozwiązania, nieznane prawu polskiemu. Należy tu w szczególności lagodniejsza odpowiedzialność nieletnich do lat 16. Tak więc ujęci na kradzieży nieletni nawet $w$ wypadku recydywy nie mogli być wydani $w$ ręce kata, a ulegali tylko skarceniu, podczas gdy rodzice lub opiekunowie winni byli wynagrodzić wyrządzoną szkodę ${ }^{28}$. Odnosiło się to nie tylko do młodzi szlacheckiej, ale też do dzieci ludzi prostych lat niedoroslych (rozdz. XIV, art. 11). Również przy zabójstwie nieumyślnym lub z przypadku praktyka polska w XVII w. przyjęla postanowienia III Statutu (rozdz. XI, art. 23), który przewidywal zapłatę kary prywatnej (główszczyzny), uwalniając sprawce od kary na gardle czy kary więzienia.

Wplyw litewskiego prawa prywatnego na polskie pozostaje jeszcze niemal $w$ całości do zbadania. O tym że istniał, świadczy fakt, iż tzw. czwarcizna - część spadkowa córek w wysokości $1 / 4$ majątku, niezależnie od liczby ich i synów, pojawiła się już w I Statucie (rozdz. IV, art. 7) i była powtarzana $w$ następnych (D. rozdz. $V$ art. $3 \mathrm{i} \mathrm{T}$. rozdz. V, art. 30 ), gdy w prawie polskim upowszechnila się dopiero w ciągu XVII stulecia.

Najmniejszy musiał być wpływ procesu litewskiego, gdyż polskie prawo ziemskie posiadało - jak wiemy - kodyfikację prawa procesowego, która na ogół spełniała swoje funkcje.

7. W dobie Oświecenia, kiedy na porządku dziennym stanęła sprawa kodyfikacji prawa wspólnego dla całej Rzeczypospolitej, podstawą jej miał się stać III Statut. Konstytucja 1768 r. poleciła przygotować projekt korektury prawa najpierw ze Statutu litewskiego, potem z korektury pruskiej, a na ostatek $z$ powszechnego cywilnego rzymskiego lub innych obcych praw wszelkich $^{29}$. W osiem lat potem król Stanisław August w orędziu od tronu odczytanym na sejmie walnym 11 września 1776 r., które zainaugurowało prace nad Zbiorem praw Andrzeja Zamoyskiego, wymieniając jako największe pomniki prawa Rzeczypospolitej Statut Laskiego i III Statut litewski,

\footnotetext{
$\overline{28} \mathrm{~J}$. R a facz, Z wplywów prawa litewskiego na prawo koronne polskie, [w:] Pamiętnik VI Powszechnego Zjazdu..., t. I, s. 204-208.

${ }^{29} \mathrm{VL}$, t. VII, s. 711 (wyd. 1860, s. 332)
} 
podniósł wage ostatniego, który Lew Sapieha kanclerz litewski [...] podal potomności do tym sprawiedliwszego szacunku, że szczésiliwie $i$ użytecznie korzystaja z niego po dziś dzień obywatele Wielkiego Ksiestwa Litewskiego, a przez wiele województw koronnych żqdany, aby sie obrócil dla nich $w$ prawo. Wywód swój król zakończył wyrażając życzenie, abyśmy na ostatek doszli tego szczesścia w Koronie, którym sie Litwa szczyci $i^{30}$.

W dobie Sejmu Czteroletniego, gdy deputacja (Komisja) konstytucyjna uchwaliła w roku 1790 wyznaczenie deputacji do ułożenia kodeksu prawa cywilnego, zobowiązała ją, że deputacja najprzód Statut Wielkiego Księstwa Litewskiego do przejrzenia i przyjęcia ogólnie na caly kraj przedsieweźmie, a gdzie by jakowy $w$ tym Statucie niedostatek nalazla, do dopetnienia tego niedostatku użyje Statutu Laskiego, zgodnie utrafiają do ulożenia prawa cywilnego ${ }^{31}$. Prymat III Statutu jako podstawy kodyfikacji dla całej Rzeczypospolitej w tej uchwale nie ulega wątpliwości.

Po uchwaleniu konstytucji 3-go Maja 1791 r. powrócono do myśli o opracowaniu wspólnego dla całej Rzeczypospolitej systemu prawa. Z projektem takim wystąpił 23 czerwca na posiedzeniu Sejmu Hugo Kołłątaj - podkanclerzy i współtwórca świeżo uchwalonej konstytucji majowej. W swoim przemówieniu nie szczędził on pochwał pod adresem III Statutu. Mówiqc o Statucie litewskim -- stwierdzal - mówie o księdze, której bez winnego uwielbienia wspomnieć nie można. Dzielo to [...] czyniqc nieśmiertelna slawe dla Lwa Sapiehy oraz rozumowi ludzkiemu, iz $w$ wieku owym, gdzie światlo nauk za czasów jagiellońskich u nas rozkrzewione gasnać już zaczynalo, Statut litewski, osobliwie co do stopniów kary, tak wszedzie jest ulożony, iż może sie uważać za najdoskonalsza praw ksiege w calej Europie, wyjqwszy niektóre wady od opinii narzucone, wyjqwszy zbyteczna $w$ karach srogość, przyware wieku onego, który nie mial jeszcze nauczycielem margrabie Beccaria ${ }^{32}$. Tak z wysoce pozytywną oceną żywego dziedzictwa czasów Odrodzenia lączył Kołłątaj krytyczne spojrzenie wieku Oświecenia na dawny, niehumanitarny system kar.

Posłowie i senatorowie litewscy jednak nie godzili się na wspólny kodeks. Zażądali oni osobnej litewskiej deputacji prawodawczej, na co Sejm Czteroletni zgodził się. Szło to - sądzić należy - w parze $\mathrm{z}$ uchwaleniem 20 października 1791 r. jako prawa konstytucyjnego Zaręczenia Wzajemnego Obojga Narodów, które zacieśniając więź Korony i Litwy, zachowywało jednak federacyjny charakter Rzeczypospolitej. To wycofanie $\mathrm{z}$ pozycji unitarnych spowodowane było oporem reprezentantów Wielkiego Księstwa. $\mathrm{W}$ tej sytuacji zwolennicy ujednolicenia prawa w skali całej Rzeczypospolitej

\footnotetext{
${ }^{30}$ Szerzej o tym E. B ork owska-B a gi eń s k a, Zbiór praw sqdowych Andrzeja Zamoyskiego, Poznań 1986, s. 52 n.

${ }^{31}$ S. B or owsk i, Kodeks Stanislawa Augusta. Zbiór dokumentów, Warszawa 1939, s. 1.

${ }^{32}$ Ibidem, s. 17-18.
} 
postanowili przyjąć III Statut jako podstawę prac kodyfikacyjnych dla Królestwa Polskiego ${ }^{33}$, by tą drogą osiągnąc unifikację prawa w calej Rzeczypospolitej.

Zdaniem Zbigniewa Zdrójkowskiego, przyjęcie litewskiego prawa prywatnego przez Koronę nie napotkałoby na większe trudności. Polskie prawo ziemskie posiadało bowiem $\mathrm{w}$ tej dziedzinie nie tylko wielkie luki, ale brakowało mu w ogóle ustawowego uregulowania tak ważnych działów, jak: zobowiązania, spadkobranie ustawowe itp. W rezultacie - stwierdza on - orzecznictwo $w$ Koronie $w$ dziedzinach nie uregulowanych przez ustawodawstwo polskie, mialo tendencje [...] rozstrzygać tego rodzaju sprawy na podstawie prawa litewskiego. Recepcja prawa karnego III Statutu napotkałaby - sądził ten autor - na większe przeszkody ze względu na łagodniejsze przepisy, a zwłaszcza praktykę prawa polskiego w porównaniu z litewskim. Niemniej w programic kodyfikacji karnej pióra Józefa Szymanowskiego z $1792 \mathrm{r}$. autor jej postulowal, by rozdzialy XI-XIV Statutu litewskiego były dobrze [...] $w$ każdym artykule rozważone $i z$ prawidlami $w$ niniejszym projekcie wylożonymi, pilnie zniesione ${ }^{34}$.

8. Przekonanie o aktualnej nadal jeszcze w XIX w. wartości III Statutu litewskiego $w$ świadomości prawnej elity społecznej $i \mathrm{w}$ nauce przetrwało upadek polityczny Rzeczypospolitej. W latach 1813-1814 książę Adam Czartoryski postulując połączenie Księstwa Warszawskiego z tzw. guberniami zachodnimi (Litwą, Białorusią i Ukrainą), proponowal cesarzowi Aleksandrowi I zniesienie w Księstwie Warszawskim Kodeksu Napoleona i innych nowo wprowadzonych praw, a zastąpienie ich przez III Statut litewski i dawną polską organizację sądów ${ }^{35}$, która - jak wiadomo - została recypowana $w$ zasadzie przez prawo litewskie. Jako obowiązujący system prawa, III Statut był przedmiotem zainteresowania i badań na ówczesnym Uniwersytecie Wileńskim. W 1818 r. Rada Uniwersytetu zleciła młodemu J. Danilowiczowi napisanie rozprawy na temat: Kodeks Napoleona w porównaniu $z$ prawami polskimi $i$ litewskimi ${ }^{36}$. Treścią rozprawy było zestawienie Kodeksu Napoleona z III Statutem jako dwóch systemów obowiązującego prawa. $Z$ wywodów autora wynikało, że stanowiły one obiekty porównywalne.

Znajomość III Statutu wyniósł z domu Adam Mickiewicz, którego ojciec - Mikolaj był członkiem palestry (adwokatem) w Nowogródku. Poeta

${ }^{33}$ Z. Zdrójkowski, Nieznane litewskie prospekty karne Józefa Weyssenhoffa z 1792 roku (nowo odnalezione materialy do dziejöw kodyfikacji Stanislawa Augusta), CPH 1958, t. X, z. 1, s. 91-123.

${ }^{34}$ Ibidem, s. 17-18.

${ }^{35}$ H. Grynwaser, Kodeks Napoleona w Polsce, [w:] Pisma, t. I, Wroctaw 1951, s. 68-73.

${ }^{36}$ I. Danilowicz, Kodeks Napoleona..., z autografu wyd. A. Kraushar, Warszawa 1905, ss. 177. 
pogłębił ją w czasie swoich studiów uniwersyteckich, kiedy pomagal J. Daniłowiczowi w poszukiwaniach rękopisów, a także egzemplarzy różnych wydań III Statutu ${ }^{37}$. Mickiewicz pozostawal pod urokiem języka prawniczego III Statutu, którego polski przekład, jeszcze z początku XVII w., bardzo wierny, był pozbawiony - co było w ówczesnym języku prawniczym wyjątkiem - wtrętów lacińskich, oddając precyzyjnie zachodnioruski (starobiałoruski) tekst oryginału. Przekład przyswajał jednocześnie polszczyźnie wiele tegoż oryginahu terminów, wśród nich także wyrazy i terminy litewskie ${ }^{38}$. Jak stwierdzal Mieczysław Jastrun, jeszcze w późnych latach życia A. Mickiewicz mówil o języku III Statutu jako o najharmonijniejszym i najmniej skażonym ze wszystkich dialektów slowiańskich ${ }^{39}$.

Znajomość instytucji i realiów życia prawnego Litwy pod rządami III Statutu znalazły wyraz w Panu Tadeuszu - eposie o sporze granicznym, którego obiektem byl zamek Horeszków, a bohaterami również prawnicy reprezentujący całą niemal hierarchię sądów lokalnych (sędzia, podkomorzy, asesor, rejent, woźny). Poeta świadomie eksponował swoje prawnicze przywiązania i sentymenty, pisząc w liście do przyjaciela. 19 kwietnia 1834 r.: $W$ moim nowym dzielku, które drukuja, scena toczy sie na Litwie, znajdziesz opisy naszego życia domowego, koncepty palestrantów, polowania etc. Pisanie tych rzeczy bawilo mnie niezmiernie, przenoszac mnie $w$ nasze mile strony rodzinne ${ }^{40}$. Dzięki geniuszowi Mickiewicza terminologia i słownictwo III Statutu weszły na trwałe do skarbnicy literackiej polszczyzny ${ }^{41}$. I to wzbogacenie narodowej kultury zawdzięczamy Statutowi Wielkiego Księstwa Litewskiego z $1588 \mathrm{r}$.

\footnotetext{
${ }^{37}$ S. Breyer, Spór Horeszków z Soplicami. Studium z dziedziny problematyki prawnej „Pana Tadeusza", Warszawa 1955, s. 14 n.

${ }^{38}$ M. T. Lizis ow a, Studia nad slownictwem regionalnym III Statutu litewskiego, Kielce 1984, S. 191-207.

${ }^{39}$ M. J a stru n, Mickiewicz, t. I, wyd. 3, Warszawa 1950, s. 9.

${ }^{40}$ A. M ickiewicz, Dziela wszystkie, t. XI, wyd. Pini i Reiter, s. 134.

${ }^{41}$ J. T r y p u ćk o, Źródla jezyka Mickiewicza, [w:] Adam Mickiewicz, Londyn 1958, s. 315-348; H. T u r sk a, Prowincjonalizmy jezykowe w „Panu Tadeuszu”, [w:] Wybór pism (1945-1962), Toruń 1984, s. 23 n.; M. T. Li izis ow a, Prawem squdzić czyli o jezyku Statutów litewskich w Panu Tadeuszu, Kraków 1998, s. 164
} 